\title{
AN INVESTIGATION OF THE GERMAN DOMINANCE HYPOTHESIS IN THE CONTEXT OF EASTERN ENLARGEMENT OF THE EU
}

\author{
Mete Feridun*
}

\begin{abstract}
:
This paper is aimed at testing the German Dominance Hypothesis (GDH) in the context of Eastern enlargement of the EU based on the hitherto unexamined former Eastern Bloc countries of Slovakia and Czech Republic using macroeconomic data spanning the period between 1991 and 2004. Cointegration analysis and a vector error correction mechanism validate the GDH. This finding raises the question of what drives these linkages and causes them to register these characteristics. While one could make the case that the Treaty of Maastricht may have caused some form of macroeconomic convergence and thus cointegration, it could also well be argued that, given our country sample and the fact that our data refers to the interbank market, these linkages may be more resulting from changes in the European banking sector and financial markets as the latter prepared for the adoption of the euro and responded to the harmonization of European banking and financial market regulations via the EU Banking Directives.
\end{abstract}

Keywords: German Dominance Hypothesis, integration, vector error correction mechanism

JEL Classification: C32, C52, E43

\section{Introduction}

Major achievement of the process of European integration in economic terms is the establishment of economic and monetary union. This article focuses on two former Eastern bloc Member States of the EU: the Czech Republic and Slovakia attempting to test the so called German Dominance Hypothesis (GDH), the main variant of the financial integration literature for Europe. To our knowledge, there exists no study in the literature testing the GDH for the Czech Republic and Slovakia. Therefore, the present study aims at filling this gap in the literature of financial integration. In line with the previous studies in the literature, the present study attempts to apply cointegration analysis and an error correction to test the GDH mechanism for

\footnotetext{
*) Faculty of Economics and Administrative Sciences, Cyprus International University, Nicosia (email: Mete.feridun@lycos.com).
} 
these two new Member Countries of the EU using macroeconomic data spanning the period between 1991 and 2004. This article is structured as follows. Section 2 reviews the literature, section 3 presents the data and methodology, and the last section presents the conclusions.

\section{Literature Review}

In the previous studies, several authors, such as Henry and Weidman (1995), have found evidence that supports the existence of GDH by applying a VAR framework using interest rates. Other authors, using different econometric methods, conclude that there may be some independence in setting the monetary policy in the European Monetary System (EMS). This is the case of Fratianni and von Hagen (1990), von Hagen and Fratianni (1990). Consequently, the empirical literature is not conclusive: the data and techniques employed are different and, most important, the authors decided to work with different and relatively small samples on the grounds of the stages and shocks which the EMS has gone through. There is a large applied econometric literature which examines the interest rate linkages within the EMS. Those papers attempt to determine whether the German dominance hypothesis can be supported. One line of literature argues that Germany has imposed its policies on other EMS Members (inter alia Giavazzi and Giovannini (1989), Artus \& al. (1991), Karfakis and Moschos (1990), Hassapis et al. (1999), Henry and Weidman (1995). In contrast Fratianni and von Hagen (1990, 1990a), von Hagen and Fratianni (1990), Katsimbris (1993) reject the German dominance hypothesis. Uctum (1999) uses an error correction vector autoregression analysis to investigate the block-exogeneity assumption among France, Germany, Italy and the USA. He also analyses the impulse responses of interest rates to innovations from the different countries. Those tests are conducted under two assumptions. The first one is that the US interest rate is not affected instantaneously by the European innovations. The second one is that the French and Italian rates are exogenous to the final targets. Such tests are essentially tests of short-run dynamic linkages among the EMS interest rates using short-run restrictions. He concludes that the tests refute the German dominance hypothesis. A few studies which explicitly consider long-run relationships are worth mentioning. Camarero and Ordóńez (2001) use cointegration tests that allow for structural changes for nine EMS countries. Their tests are performed in a trivariate framework including the US rate as a third variable. They find that short-run causality exists between Germany and the UK, however, they find no longrun causality in the 1990s. They argue that the UK regained its independence after leaving the EMS in 1992. Bajo-Rubio and Montáves-Garcès (2002) find no longrun causality between the UK and Germany but they find one way short-run causality from Germany to the UK in the 1990s. This result is confirmed by Artis and Zhang (1998) who also find no cointegration after 1991. Analysts such as Obstfeld (1989, 1994, 1995) and Bayoumi and MacDonald (1995) have attempted to gauge the extent and impact of financial integration between countries by utilizing macroeconomic variables, such as consumption, examining how the latter behaves across different national borders. The rationale for this stream of research suggests that high correlations between domestic and foreign consumption represent the effects of diversification actions by investors and implies therefore high capital mobility 
and deep financial integration. A number of analyses have tested for the existence of co-integrating relationships between these variables and have focused mainly on Europe, not least because of the particular and unique character of European financial integration in the world economic history, and the relative abundance of national data regarding this project. Analyses within this research category have attempted either to assess the impact of financial deregulation measures aimed at overcoming the fragmentation of EU financial markets as the latter was identified in the Cecchini Report (1988) or to examine the degree of financial integration between Germany and other EU countries. The latter research field in particular has been framed in terms of the German dominance hypothesis whereby researchers have applied various econometric tests on EU Member States' national interest rate data in order to see whether Germany dominates the setting of interest rates in the EU. The results of the studies attempting to provide an answer to the GDH have been far from unanimous. Thus Karfakis and Moschos (1990) employing bivariate vector autoregression analysis within an interest rate parity framework, test whether an interest rate linkage existed between Germany and Belgium, France, Ireland, Italy and the Netherlands during the days of the EMS. They use monthly data of short-term domestic interest rates between April 1979 and November 1988 taking into account differences in national taxation. Their findings suggest that for the period examined, German interest rate changes contained information on changes in the interest rate changes of the other countries in the sample with the exception of Ireland. The observed existence of an unidirectional interest rate causation linkage from Germany to the other EMS countries, in spite of the existence of capital controls, constituted in the researchers' opinion irrefutable evidence in favour of the GDH. This finding is questioned by Katsimbris and Miller (1993) who argue that the interest rates of the countries participating in the EMS could have been influenced by interest rate changes in countries other than Germany. Thus using the same EU countries for the same time period but including the US in their analysis, Katsimbris and Miller develop a bivariate and trivariate model of interest rate linkage. For the bivariate model the results are mixed: the German interest rate Granger-causes the other countries interest rates while the US interest rate appears to Grangercause and be caused in turn by interest rate changes in Germany, Ireland, Italy and the Netherlands. Their trivariate model findings present an even more complicated picture: Germany appears to influence and be influenced by the other countries of the sample including the US, thus presenting evidence against the GDH. If German interest rates explain but are also explained by other countries' interest rates, how then can one say that Germany dominates interest rate setting in Europe? These doubts are echoed in the findings not only of Fratianni and von Hagen (1990) but also of de Grauwe (1989) who inquires whether the EMS is a Deutchmark zone. Using monthly short and long- term interest rate data and controlling for US influence, de Grauwe performs Granger causality tests finding that in the short-term Germany Granger-causes Dutch interest rates while a mutual feedback relationship exists between Germany, France and Belgium. In the long term, the study identifies a direction of causation from France towards Germany reporting insignificant results for the other countries, with the exception of Italy whose interest rates appear to have been caused by German interest rate changes. The lack of evidence for the existence of German dominance within the European financial system is further 
enhanced by the study of Hassapis et al (1999). Applying a Johansen cointegration methodology in the same country sample as the studies above, Hassapis et al find that EMS country interest rates are cointegrated with those of the US but not with those of Germany. An even more surprising finding appears to be the fact that Germany's interest rates are caused by, rather than cause, interest rate changes in the other European countries thus placing the GDH under an even greater question mark. Similar results questioning the GDH are reported in Caporale et al (1996), von Hagen and Fratianni (1990) and Koedijk and Kool (1992) only to be contradicted by Herz and Roger (1992) and Poeck and Gombel (1994) whose findings suggest an unambiguous preponderance of Germany in EU economic affairs. German preponderance in interest rate setting within Europe is given further support by the findings of Baum and Barkoulas $(2001,2002)$, who examine the dynamics of EMS interest-rate linkages. Using a fractional error correction model the authors provide evidence in favour of the GDH.

\section{Data and Methodology}

Traditionally, the GDH has been tested by analyzing the existence or absence of Granger causality from German monetary policy to those of other countries. Monetary aggregate and short-run interest rates have commonly been used in order to study the reaction of monetary authorities to monetary innovations coming from other countries. According to Sims (1992), if the monetary authorities accommodate changes in money demand, the monetary aggregates cannot correctly reflect shifts in monetary policies. Moreover, Bernanke and Blinder (1992) have shown that the most accurate indicator of monetary policy in the short run is the interest rate, that is, the rate that central banks can control very closely. Following these considerations, we use 3-month interest rates as indicators of monetary policy. Uncovered interest rate parity for two assets that are perfect substitutes of each other and are traded in different currencies conforms to the following relationship:

$$
\left(1+i_{1 t}\right)=\left(1+i_{2 t}\right) f_{t} / S_{t}
$$

where $i_{1 t}$ and $i_{2 t}$ are the interest rates at time $t$ in countries 1 and 2 respectively, while $f_{t}$ and $s_{t}$ refer to the forward and spot foreign exchange rates between the given countries' currencies prevalent at time $t$. Assuming that investors are risk-averse the forward rate at time $t$ will reflect their expectations regarding the spot rate at a time in the future, for example, $t+1$, plus a premium $\pi_{t}$ compensating for the perceived riskiness of holding domestic assets. Thus we have:

$$
f_{t}=E_{t}\left(s_{t+1}\right)+\pi_{t}
$$

Taking the logs on both sides of (1) and rearranging we have :

$$
I_{1 t}-I_{2 t}=f_{t}-s_{t}
$$

Substituting (2) in (3) we get:

$$
I_{1 t}-I_{2 t}=E_{t}\left(s_{t+1}\right)+\pi_{t}-s_{t}=>I_{1 t}-I_{2 t}=E_{t}\left(s_{t+1}\right)-s_{t}+\pi_{t}
$$

As (4) cannot be empirically tested due to the lack of observations on market expectations, we assume that foreign exchange markets are rational meaning that 
the value the spot exchange rate $s$ realized in time $t+1$ is equal to the value expected by investors at time $t$ plus a prediction error $u_{t, t+1}$. In other words we would have:

$$
s_{t+1}=s_{t, t+1}+u_{t, t+1}
$$

Substituting in (4) we would have

$$
I_{1 t}-I_{2 t}=\left[E_{t}\left(s_{t, t+1}\right)-s_{t}\right]+\pi_{t}+E\left(u_{t, t+1}\right)
$$

In terms of the stochastic properties of the components of equation (6), the expectations error in the parenthesis is white noise and is therefore stationary while the risk premium $\pi_{t}$ reflecting shifting investor expectations to daily currency rate fluctuations is stationary as well. Exchange rates have been, according to the literature (Meese and Rogoff, 1983), displaying random walk behaviour and can therefore be safely assumed that they are stationary as well. Thus if the right-hand side of (6) is stationary then that means that the left-hand side must be stationary as well indicating the occurrence of cointegration. Yet, before investigating whether cointegrating relationships exist between a set of variables, we must establish that our data are stationary and thus find the order of integration of our time series. For the latter purpose we employ unit root analysis through the Augmented Dickey Fuller (ADF) test which consists of running a regression of the first difference of the series against the series lagged once, lagged difference terms, and optionally, a constant and a time trend. This can be expressed as:

$$
\Delta y_{t}=\beta_{1} y_{t-1}+\beta_{2} \Delta y_{t-1}+\beta_{3} \Delta y_{t-2}+\beta_{4}+\beta_{5} t
$$

The test for a unit root is conducted on the coefficient of $y_{t-1}$ in the regression. If the coefficient is significantly different from zero then the hypothesis that y contains a unit root is rejected. Rejection of the null hypothesis implies stationarity. If the calculated ADF statistic is higher than McKinnon's critical value then the null hypothesis is not rejected and it is concluded that the considered variable is nonstationary, i.e. has at least one unit root. Then, the procedures are re-applied after transforming the series into the first differenced form. If the null hypothesis of nonstationarity can be rejected, it can be concluded that the time series are integrated of order one, $I(1)$. If cointegration exists then the relationship of the variables can be modelled in such a way as to take into account short-run deviations from the long-run relationship as the latter is expressed by equation (10). This is achieved with the estimation of an Error Correction Model (ECM), entailing the inclusion of both the long-run relationship and the short-run deviations as given below:

$$
\begin{gathered}
\Delta Y_{t}=a_{1,0}+a_{1,1}\left(Y-b_{0}-\beta X\right)_{t-1}+\sum \gamma_{1, j} \Delta Y_{t-j}+\sum \zeta_{1, j} \Delta X_{t-j}+e_{1, t} \\
\Delta X_{t}=a_{2,0}+a_{2,1}\left(Y-b_{0}-\beta X\right)_{t-1}+\sum \gamma_{2, j} \Delta Y_{t-j}+\sum \zeta_{2, j} \Delta X_{t-j}+e_{2, t} \\
e_{t-1}=Y_{t-1}-b_{0}-\beta X_{t-1}
\end{gathered}
$$

The adjustment of our series as indicated in (12) and (13) is decomposed into a short-run and a long-run component. The short-run component is provided by the two $\left(\sum\right)$ summation terms on the right-hand side of each equation, while the longrun component is represented by the term in the parentheses that stands for the lagged values of the residual from (10) and given in (14). This term provides eviden- 
ce of convergence and restoration of the long-run relationship between the variables. Cointegration existing, this term is expected to move in the opposite direction from any short-run deviations that may take place and restore equilibrium. According to Granger (1969), Y is said to "Granger-cause" $X$ if and only if $X$ is better predicted by using the past values of $Y$ than by not doing so with the past values of $X$ being used in either case. In short, if a scalar $Y$ can help to forecast another scalar $X$, then we say that $Y$ Granger-causes $X$. If $Y$ causes $X$ and $X$ does not cause $Y$, it is said that unidirectional causality exists from $Y$ to $X$. If $Y$ does not cause $X$ and $X$ does not cause $Y$, then $X$ and $Y$ are statistically independent. If $Y$ causes $X$ and $X$ causes $Y$, it is said that feedback exists between $X$ and $Y$. Essentially, Granger's definition of causality is framed in terms of predictability. Granger (1969) originally suggested the Granger test, which was improved by Sargent (1976). To implement the Granger test, we assume a particular autoregressive lag length $k$ (or $p$ ) and estimate equation (5) and (6) by OLS:

$$
\begin{aligned}
& X_{t}=\lambda_{1}+\sum_{i=1}^{k} a_{1 i} X_{t-i}+\sum_{j=1}^{k} b_{1 j} Y_{t-j}+\mu_{1 t} \\
& Y_{t}=\lambda_{2}+\sum_{i=1}^{p} a_{2 i} X_{t-i}+\sum_{j=1}^{p} b_{2 j} Y_{t-j}+\mu_{2 t}
\end{aligned}
$$

$F$ test is carried out for the null hypothesis of no Granger causality $H_{0}: b_{t 1}=b_{t 2}$ $=\ldots=b_{t k}=0, i=1,2$, where $F$ statistic is the Wald statistic for the null hypothesis. If the $F$ statistic is greater than a certain critical value for an $F$ distribution, then we reject the null hypothesis that $Y$ does not Granger-cause $X$ (equation (1)), which means $Y$ Granger-causes $X$. We use monthly 3-month interbank (offered) rate data from DataStream but also official institutional publications. We use the Augmented Dickey-Fuller test (ADF) in order to check for the stationarity of our data, employing different numbers of lags each time including a constant but not a trend in our modelling in Eviews (Dickey and Fuller, 1981). As our dataset consists of monthly observations, we started from a high number of 30 and 24 lags and moved backwards reducing the number of lags based on the Akaike information criterion. The results for our tests at the levels for different lags are given in Tables 1 and 2 below, indicating that the hypothesis cannot be rejected, in other words, we have nonstationarity.

Table 1

ADF Test Statistic Results - Levels

\begin{tabular}{|l|c|c|c|c|}
\hline No. of lags & 3 & 6 & 10 & 12 \\
\hline Slovakia & -1.343241 & -1.05234 & -1.23422 & -1.83422 \\
\hline Czech Republic & -2.034234 & -2.53423 & -1.42342 & -1.23423 \\
\hline Germany & -1.142342 & -1.54323 & -2.16032 & -2.23432 \\
\hline USA & -1.623422 & -2.02423 & -2.20423 & -2.34242 \\
\hline $\begin{array}{l}\text { critical values } \\
\text { at } 10 \%\end{array}$ & -2.643232 & -2.53422 & -2.63423 & -2.53422 \\
\hline
\end{tabular}


Table 2

ADF Test Statistic Results - First Differences

\begin{tabular}{|l|c|c|c|}
\hline No. of lags & 0 & 3 & 4 \\
\hline Slovakia & -10.53341 & -6.01235 & -5.12329 \\
\hline Czech Republic & -7.633234 & -5.70422 & -4.95236 \\
\hline Germany & -10.40142 & -3.41326 & -3.26532 \\
\hline USA & -6.323452 & -3.42327 & -2.62342 \\
\hline critical values at $10 \%$ & -2.643232 & -2.53422 & -2.58234 \\
\hline
\end{tabular}

As argued by Arulampalan (2000) regression between 2 variables of different order, namely I(0) and I(1), would not make sense since the I(1) will have a dominant impact and thus introduce bias towards rejection of cointegration when testing the stationarity of the regression's residuals. In order to resolve this ambiguity, we take the first difference and apply the ADF test again with different lags. We start again from a high number of lags and go backwards based on the Akaike information criterion. The results are presented in Table 3 below, indicating that the data from both countries is integrated of order one, i.e. I(1) as the null hypothesis of nonstationarity is rejected. We then move on and test whether our time series are cointegrated by running regressions of the form specified in equation (10). With respect to interest rates the equation becomes for the case of bivariate cointegration:

$$
\begin{aligned}
& I_{c, t}=b_{0}+I_{D, t}+e_{t} \\
& I_{c, t}=b_{0}+I_{U S, t}+e_{t}
\end{aligned}
$$

where Ic,t stands for country C's interest rate at time t, and I D,t and I US,t stand for the interest rates of Germany and the US, respectively. In both cases we save

Table 3

\begin{tabular}{|l|l|l|l|}
\hline $\begin{array}{l}\text { ADF Test stats (no of } \\
\text { lags in parantheses) }\end{array}$ & Germany & USA \\
\cline { 2 - 4 } & Slovakia & $-4.134222(0)$ & $-2.523542(0)$ \\
\cline { 2 - 4 } & Czech Republic & $-4.212411(2)$ & $-2.263242(0)$ \\
\hline $\begin{array}{l}\text { Critical values for } \\
\text { sample size of 50 }\end{array}$ & 0.01 & -4.12 & $\begin{array}{l}\text { Original sample } \\
\text { size } \text { 93 with } \\
\text { variables }\end{array}$ \\
\hline $\begin{array}{l}\text { Critical values for } \\
\text { sample size of 100 }\end{array}$ & 0.05 & -3.29 & \\
\cline { 2 - 4 } & 0.10 & -2.91 & \\
\cline { 2 - 4 } & 0.01 & -3.72 & \\
\cline { 2 - 4 } & 0.05 & -3.17 & \\
\cline { 2 - 4 } & 0.10 & -2.91 & \\
\hline
\end{tabular}


the regressions' resultant residuals and subject them to ADF tests with different, however, critical values from the traditional ADF test (Engle and Yoo, 1991). If we have stationarity then our variables are cointegrated, i.e. there exists a long run relationship between them and their relationship can be modelled via the development of Error Correction Models (ECM). If we do not have stationarity then there is no long-run relationship between our variables; as we cannot develop ECM we investigate whether there are any short-run linkages between the countries' interest rates and try to detect short-run causality using Granger causation analysis with respect to Germany.

It emerges from the above results that the null hypothesis of non-cointegration can be rejected for our time series. Table 4 below summarizes the long-term relationships based on cointegration test results.

Table 4

\section{Long-Term Relationships Based on Cointegration Test Results}

\begin{tabular}{|l|c|c|}
\hline Reject Ho of no cointegration & Germany & USA \\
\hline Slovakia & Yes & No \\
\hline Czech Republic & yes & No \\
\hline
\end{tabular}

Lag length choice is based on Akaike information criterion (AIC).

In summary, Czech and Slovak interest rates appear to share a long-run relationship with German rates. Thus we proceed by developing Error Correction models through estimating a model for each country according to equation (12) using Germany as the reference country. We try different lag specifications adding lags and dropping insignificant differences in order to have as parsimonious final model for each country. The results are reported in Table 5.

Table 5

\section{Vector Error Correction Model Results}

\begin{tabular}{|l|l|l|l|l|l|}
\hline Variable & Coefficient & t-stat & Variable & Coefficient & t-stat \\
\hline C & -0.06754 & -1.47667 & C & 0.009754 & -0.07667 \\
\hline Residual $(-1)$ & -0.05788 & $-4.9786 * * *$ & Residual $(-1)$ & -0.24568 & $-3.9677 * * *$ \\
\hline D (Belgiom $(-1)$ & 0.066549 & 0.67658 & D (ire $(-1)$ & 0.376549 & $3.67658 * * *$ \\
\hline D (belg) $(-2)$ & 0.188799 & $1.96589 * *$ & D (ger $(-1)$ & 0.799797 & $1.84796 * *$ \\
\hline D (germ) $(-1)$ & -0.37659 & $-1.7589 * *$ & \multicolumn{4}{|l}{} \\
\hline
\end{tabular}

$*$ denotes significance at $1 \%, * *$ denotes significance at $5 \%, * * *$ denotes significance at $10 \%$

As Table 5 reveals, the unidirectional relationship between our sample countries and Germany, with the speed of convergence, i.e. the restoration of long-run equilibrium as indicated by the significant coefficient of the lagged residual, being sub- 
stantial both cases. The constant $\mathrm{C}$, appears that for all the countries we have insignificance as one would expect from convergence processes.

\section{Conclusion}

The aim of this paper is to test the German Dominance Hypothesis (GDH) in the context of Eastern enlargement of the EU based on the hitherto unexamined former Eastern bloc countries of Slovakia and Czech Republic. The methodological caveats notwithstanding, the evidence presented in the study raises the question of what drives these linkages and causes them to register these characteristics. While one could make the case that the Treaty of Maastricht may have caused some form of macroeconomic convergence and thus cointegration, it could also well be argued that, given our country sample and the fact that our data refers to the interbank market, these linkages may be more the result of changes in the European banking industry and financial markets as the latter prepared for the adoption of the euro and responded to the harmonization of European banking and financial market regulations via the EU Banking Directives. Clearly these effects have a bearing on the banking sector and financial markets of our sample countries not only directly but also indirectly, as they affect developments in other EU countries with which our sample countries trade and compete. This study clearly indicates the importance of European financial integration and the existence of interest rate connection and spillover effects even for the countries being outside the formal structures of the eurozone or for those being late in joining it. How these linkages are going to affect the Member States' economies and their convergence to the income levels of the EMU core countries is by itself a major, hotly debated academic and highly sensitive political issue, whose treatment does not constitute part or aim of this paper.

\section{References}

Artis, M.J. (2001), The Economics of the European Union: Policy and Analysis Oxford: Oxford University Press.

Artus, P., Avouyi-Dovi, S., Bleuze, E., Lecointe, F. (1991). Transmission of US Monetary Policy to Europe and Asymmetry in the European Monetary System, European Economic Review, 35, pp. $1369-1384$.

Baum, C.F., Barkoulas, J. (2001-2002), 'Dynamics of Intra-EMS Interest Rate Linkages.' Paper downloaded from http://netec.mcc.ac.uk/WoPEc/data/ Papers/bocbocoec492.html.

Bajo-Rubio, O., Montávez-Garcès, M.D. (2002). Was there Monetary Autonomy in Europe on the Eve of the EMU? The German Dominance Hypothesis Re-examined, Journal of Applied Economics, 5, pp. 185-207.

Bayoumi, T., MacDonald, R. (1995), 'Consumption Income and International Capital Market Integration' IMF Staff Papers 42/3, pp. 552-576.

Bernanke, B.S., Blinder, A.S. (1992), "The Federal Funds Rate and the Channels of Monetary Transmission," American Economic Review, 82, pp. 901-921.

Calvo, G. et.al. Oxford: Oxford University Press. pp. 134-155.

Calvo, G. (1995), 'International Capital Mobility in the 1990s' in P.K Keenan (1995). Princeton: Princeton University Press. pp. 201-261. 
Caporale, G.M., Pittis, N. (1993), Common Stochastic Trends and Inflation Convergence in the EMS, Weltwirtschaftliches Archiv, 129, pp. 207-215.

Camarero, M., Ordóńez, J. (2001), Who Is Ruling Europe? Empirical Evidence on the German Dominance Hypothesis, Empirical Economics, 26, pp. 623-650.

Cecchini Report/Commission of the European Communities. (1988), European Economy: The Economies of 1992. Brussels: Directorate-General for Economic Affairs.

Cooper, I., Kaplanis, E. (1995), 'Home Bias in Equity Portfolios and the Cost of Capital for Multinational Firms.' Journal of Applied Corporate Finance 8, pp. 95-102.

De Grauwe, P. (1989), 'Is the European Monetary System a DM-Zone?' Working Paper No.297, Centre for Economic Policy Research London. Downloaded from www.cepr.org/pubs/dps/ DP297.asp. Press. (2000), The Economics of Monetary Union, 4th ed. Oxford: Oxford University

Dickey, D.A., Fuller, W.A. (1981), Likelihood Ratio Statistics for Autoregressive Time Series with a Unit Root, Econometrica 49, pp. 1057-1072.

Engle, R.F., Granger, C.W. (1987), 'Cointegration and Error Correction: Representation, Estimation and Testing.'Econometrica 55, pp. 251-276.

Feldstein, M., Horioka, C. (1980). 'Domestic Saving and International Capital Flows' The Economic Journal 90, pp. 314-329.

Fratianni, M., von Hagen, J. (1990), German Dominance in the EMS: The Empirical Evidence, Open Economies Review 1, pp. 67-87.

(1990a), The European Monetary System Ten Years After, CarnegieRochester Conference series on Public Policy 32, pp. 173-241.

Gardener, E., Molyneux, P., Moore, B. (1998), 'The Strategic Implications of EMU for European Banking' The Service Industries Journal 18/4, pp. 87-108.

Giavazzi, F., Giovannini, A. (1989), Limiting Exchange Rate Flexibility: The European Monetary System, MIT Press, Cambridge.

Hess, G.D., Shin, K. (2000), 'Risk Sharing by Households within and across Regions and Industries' Journal of Monetary Economics 45, pp. 533-560.

Hassapis, C., Pittis, N., Prodromidis, K. (1999), Unit Roots and Granger Causality in the EMS Interest Rates: the German Dominance Hypothesis Revisited, Journal of International Money and Finance 18, pp. 47-73.

Henry J., Weidman, J. (1995), The French-German Interest Rate Differential since German Unification: The Impact of the 1992 and 1993 EMS Crisis, University of Bonn, Discussion paper B-295.

Karfakis, C.J., Moschos, D.M. (1990), 'Interest Rate Linkages Within the European Monetary System: A Time Series Analysis: Note' Journal of Money, Credit and Banking 22/3, pp. 388394.

Katsimbris, G.M., Miller, S.M. (1993), 'Interest Rate Linkages Within the European Monetary System: Further Analysis' Journal of Money, Credit and Banking 25/4, pp. 771-779.

Lewis, K.K. (1999), 'Trying to Explain Home Bias in Equities and Consumption' Journal of Economic Literature Vol.37, pp. 571-608.

Meese, R.A., Rogoff, K. (1983), 'Empirical Exchange Rate Models of the Seventies: Do They Fit out of Sample?' Journal of International Economics 14, pp. 3-24.

Obstfeld, M. (1986), 'Capital Mobility in the World Economy: Theory and Measurement' NBER Working Paper No. 1692. Downloaded from http://papers.nber.org/papers/.

Sims, C. (1992), "Interpreting the Macroeconomic Time Series Facts: The effects of Monetary Policy", European Economic Review, Vol. 36, pp. 976-1000.

Sinn, S. (1992), 'Saving-Investment Correlations and Capital Mobility: On the Evidence from Annual Data' The Economic Journal 102, pp. 1162-1170. 
Taylor, A.M. (1994), 'Domestic Saving and International Capital Flows Reconsidered,' NBER Working Paper No. 4892. Downloaded from http://papers.nber.org/papers.73.

(1996), 'International Capital Mobility in History: The Saving-Investment Relationship' NBER Working Paper No. 5743. Downloaded from http://papers.nber.org/papers.

Tesar, L.L., Werner, I.M. (1992), 'Home Bias and the Globalization of Securities Markets' NBER Working Papers No. 4218. Downloaded from http://papers.nber.org/papers.

Uctum, M. (1999), European Integration and Asymmetry in the EMS, Journal of International Money and Finance 18, pp. 769-798.

Von Hagen, J., Fratianni, M. (1990), German Dominance in the EMS: Evidence from Interest Rate, Journal of International Money and Finance 9, pp. 358. 